\title{
The Jurassic fossil wood diversity from western Liaoning, NE China
}

\author{
Zi-Kun Jiang ${ }^{1,2}$, Yong-Dong Wang ${ }^{2,3^{*}}$, Ning Tian ${ }^{4,5}$, Ao-Wei Xie ${ }^{2,6}$, Wu Zhang ${ }^{7}$, Li-Qin Li ${ }^{2}$ and Min Huang ${ }^{1}$
}

\begin{abstract}
Western Liaoning is a unique region in China that bears diverse types of Jurassic plants, including leaves, fern rhizomes, and wood, providing significant proxy for vegetation and palaeoenvironment reconstruction of the well-known Yanliao Flora in East Asia. In particular, the silicified wood is very abundant in the fossil Lagerstätte of the Jurassic Tiaojishan Formation in Beipiao, western Liaoning. Previous and recent systematic investigations documented a high diversity of the Jurassic wood assemblages. These assemblages are dominated by conifers, followed by cycads and ginkgoaleans. In total, about 30 species belonging to 21 genera of fossil wood have been recorded so far, which are represented by Cycadopsida, Ginkgopsida, Coniferopsida, and Gymnospermae incertae sedis. The evolutionary implications of several distinctive fossil wood taxa as well as palaeoclimate implications are summarized based on their anatomical structures and growth ring patterns. This work approaches the vegetation development and evolutionary significances of the wood taxa and their relatives, and provides clues for the further understanding of the diversity of the Jurassic Yanliao Flora in East Asia.
\end{abstract}

Keywords: Fossil wood, Diversity, Evolution, Tiaojishan Formation, Jurassic

\section{Introduction}

Fossil floras are a significant record for the vegetation and for the palaeoenvironment reconstructions of the Mesozoic. In particular, permineralized wood represents an important proxy for floral and palaeoclimate studies. China bears numerous permineralized woods ranging in age from Late Paleozoic to Cenozoic (Zheng et al. 2008). In the twentieth century, considerable pioneering contributions were made by many authors, e.g., Gothan (1905, 1906, 1907, 1910), Chang (1929), Gothan and Sze (1933), Shimakura (1933, 1936, 1937), Mathews (1943), Hsü (1950a, b, c, 1953), and Sze (1951, 1952, 1953, 1954, 1962), which laid the foundation of fossil wood studies in China. Also, a remarkable progress has been achieved in this field in the past decades. In particular, a great number of fossil wood has been investigated from the Mesozoic strata in northeast China, including sites in Liaoning, Jilin and Heilongjiang Provinces (Sze and Lee 1963; Du 1982; Zheng

\footnotetext{
* Correspondence: ydwang@nigpas.ac.cn

${ }^{2}$ State Key Laboratory of Palaeobiology and Stratigraphy, Nanjing Institute of Geology and Palaeontology, Chinese Academy of Sciences, Nanjing 210008, Jiangsu Province, China

${ }^{3}$ Center for Excellence in Life and Palaeoenvironment, Chinese Academy of Sciences, Nanjing 210008, Jiangsu Province, China

Full list of author information is available at the end of the article
}

2004; Wang et al., 2009). Among these localities, western Liaoning is a well-known fossil Lagerstätte with diverse and well-preserved fossil plant foliages and wood (Zhang and Zheng 1987) from the Mesozoic formations in this region. Ogura (1944) first recorded a fossil wood species, Araucarioxylon jeholense Ogura based on an Early Jurassic specimen collected from the Beipiao area, which was later revised as Protosciadopityoxylon jeholense (Ogura) by Zhang et al. (2000a). In recent decades, increasing investigations that focused on wood taxonomy were carried out in the western Liaoning region (e.g., Ding et al. 2000, 2016; Duan 2000; Zhang et al. 2000a, 2006; Zheng et al. 2001; Wang et al. 2006; Jiang et al. 2008, 2016; Jiang 2012). These studies show that the Mesozoic wood taxa in western Liaoning are mainly represented by conifers, cycads, ginkgoaleans as well as other gymnosperms incertae sedis.

Among these Mesozoic deposits, the Middle-Late Jurassic Tiaojishan Formation comprises a variety of plant fossils including leaf impressions and compressions, permineralized fern rhizomes and gymnosperm woods (Wang et al. 2006). More than 35 genera and 92 species of plant megafossils, including a variety of foliages belonging to equisetaleans, ferns, cycads, bennettitaleans, ginkgoaleans and conifers, have been described from this 
formation (Zheng and Zhang 1982; Zhang and Zheng 1987; Jiang et al. 2008). In recent years, further investigations on permineralized osmundaceous rhizomes revealed diverse fossil taxa ascribed as Millerocaulis Erasmus ex Tidwell emend. Tidwell and Ashicaulis Tidwell (Zhang and Zheng 1991; Matsumoto et al. 2006; Cheng and Li 2007; Cheng et al. 2007; Yang et al. 2010; Cheng 2011; Tian et al. 2013, 2014a, 2014b). The Tiaojishan Formation is thus regarded as one of the most significant Jurassic localities and a center of species diversity with regard to osmundaceous rhizomes in the northern hemisphere (Tian et al. 2014a). However, our knowledge of the systematics and diversity of the permineralized flora in the Tiaojishan Formation is still rather limited.

In recent years, abundant fossil wood specimens were collected from the Tiaojishan Formation in Changgao town, Beipiao city in western Liaoning. In this paper, we present a systematic overview of the fossil wood diversity in western Liaoning across the Middle to Late Jurassic transition, and discuss the evolutionary implications and palaeoclimate implications based on fossil wood taxa of several major gymnosperm groups.

\section{Geological background}

In western Liaoning, one of the major fossil wood deposits is located in Changgao town in Beipiao city, which includes several localities in Lamaying, Shebudaigou, Taizishan, and Toudaogou villages of Changgao town $\left(121^{\circ} 00^{\prime}-121^{\circ} 09^{\prime}\right.$ E, $\left.41^{\circ} 43^{\prime}-41^{\circ} 47^{\prime} \mathrm{N}\right)$ (Fig. 1).

Stratigraphically, most of the wood specimens originate from the Tiaojishan Formation (formerly Lanqi Formation). This formation conformably or unconformably covers the Haifanggou Formation; and unconformably overlies the Tuchengzi Formation (Xu et al. 2003). Geographically, the Tiaojishan Formation is widely distributed in western Liaoning Province and the neighboring northern Hebei Province. This formation is lithologically composed of intermediate lava and pyroclastic rocks, interlayered with basic volcanic rocks and sedimentary deposits (Xu et al. 2003; Jiang et al. 2010a) (Fig. 2). It contains abundant and well-preserved fossil plants, including leaves, seeds and fruits, permineralized rhizomes and wood (Wang et al. 2006). Traditionally, the Tiaojishan Formation is generally considered to be the Middle Jurassic in age based on palaeontological assemblages (Zhang and Zheng 1987; Duan et al. 2009). Recent isotopic dating of ${ }^{40} \mathrm{Ar} /{ }^{39} \mathrm{Ar}$ of volcanic rock reveals an average age of $160 \mathrm{Ma}$, pointing to late Middle Jurassic to early Late Jurassic interval, which puts the Tiaojishan Formation at a Middle to Late Jurassic transition interval, corresponding to Callovian-Oxfordian in age (Chang et al. 2009).

\section{Materials and methods}

The fossil specimens used in this study were preserved as silicified wood. The techniques used for the investigation are the classical thin section method for silicified wood described in Jones and Rowe (1999). Nomenclatural and taxonomical positions follow those of Philippe (1993), Bamford and Philippe (2001) and Philippe and Bamford (2008). Photographs were taken with ACT-1C DXM1200C software adapted to a Nikon E600 transmitted light microscope. All fossil wood specimens and slides to which this study refers are housed in the Palaeobotany Collection of the Nanjing Institute of

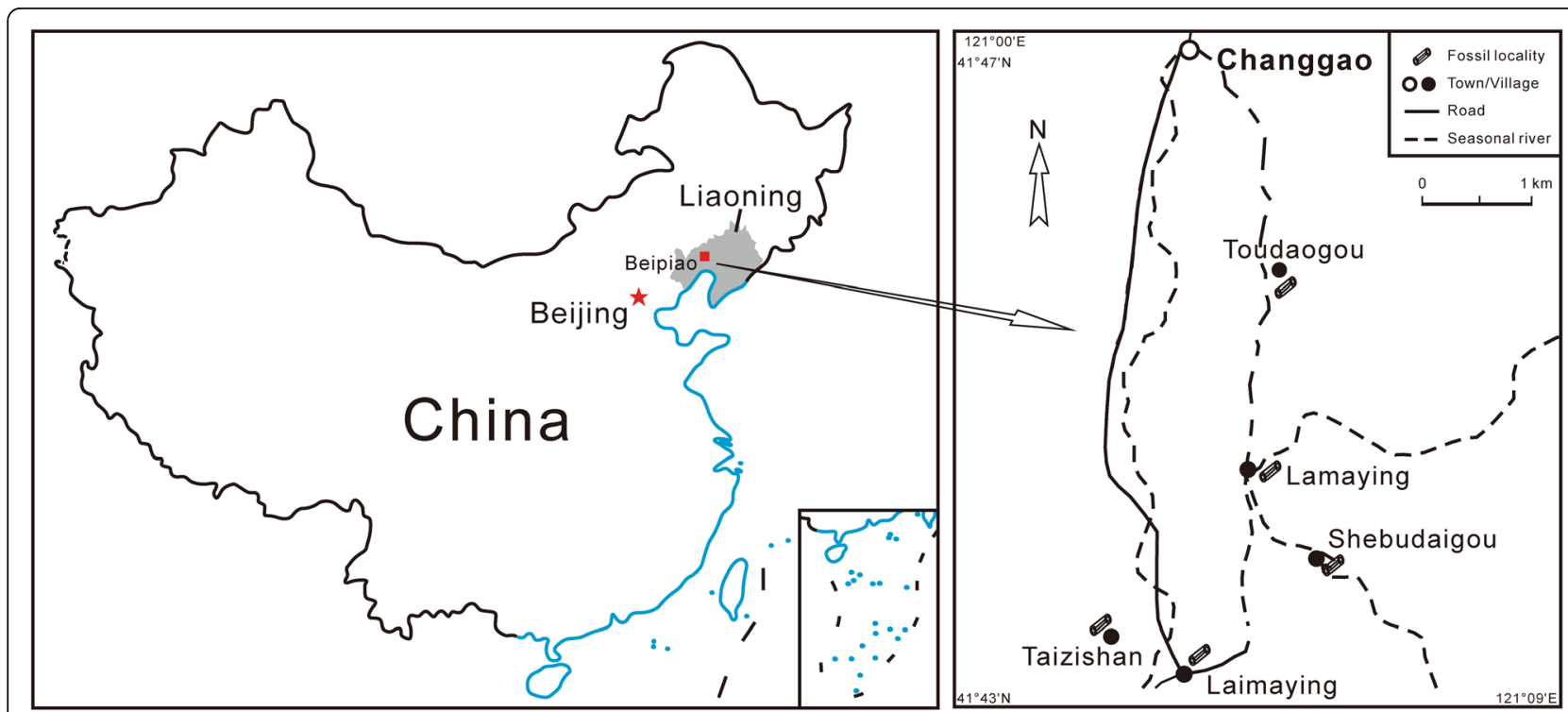

Fig. 1 Geographical localities of fossil wood in Beipiao, western Liaoning. The map of China is modified after the National Bureau of Surveying and Mapping of China (No. GS(2016)1603 and No. GS(2016)2884) 

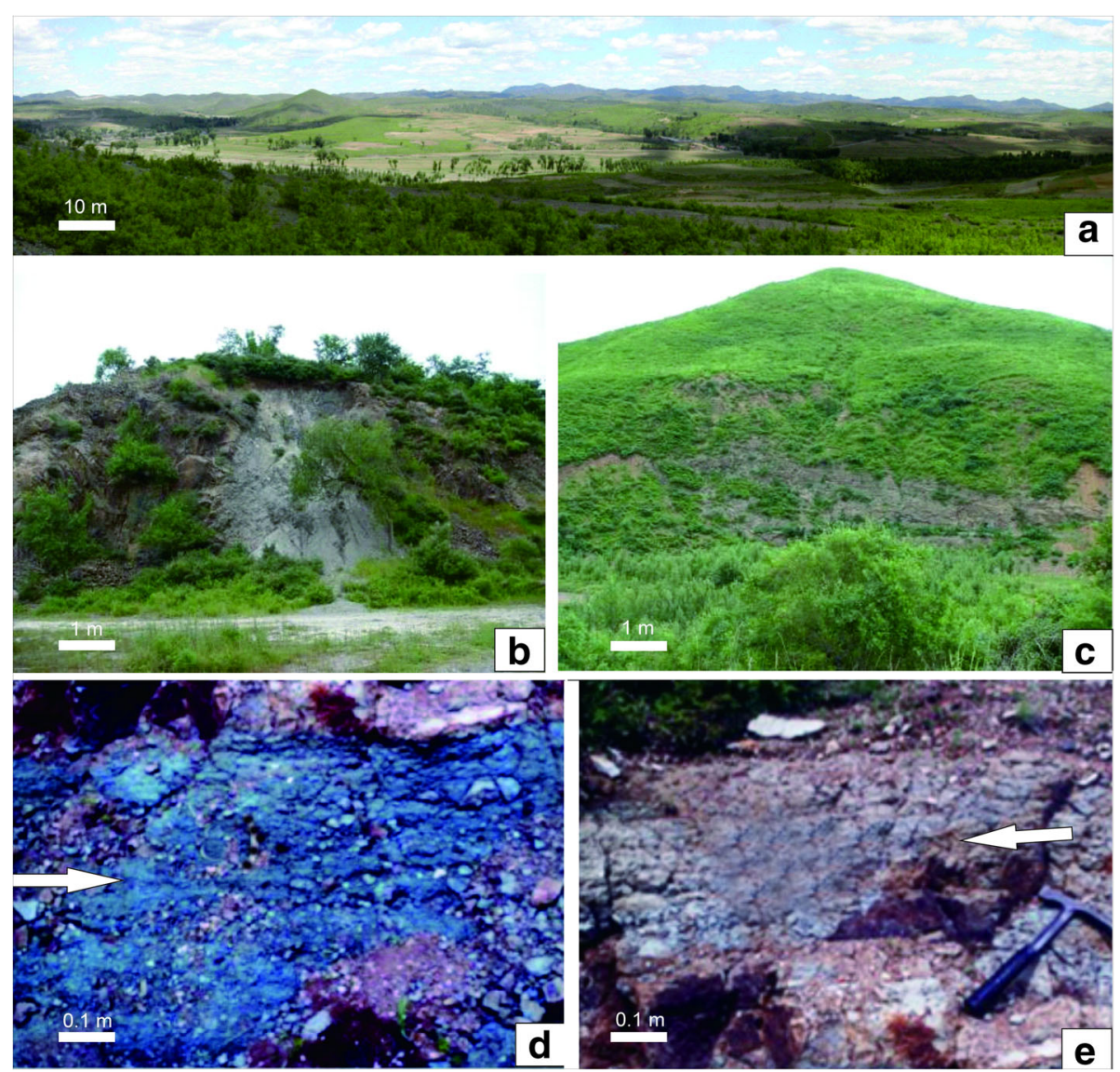

Fig. 2 The geological sections of the Tiaojishan Formation in Changgao town, Beipiao city, western Liaoning. a Bird's eye view of the fossil localities; b Lamaying section; c Taizishan section; d Interbedded sand (arrow) in the Tiaojishan Formation, Lamaying section (after Wang et al. 2006); e Tuff (arrow) in the Tiaojishan Formation, Lamaying section (after Wang et al. 2006)

Geology and Palaeontology, Chinese Academy of Sciences, in Nanjing (China).

\section{Fossil wood diversity}

\subsection{Preservation}

In China, fossil wood can be preserved as permineralized, coalified and fusainized. Permineralized woods differ from one another in accordance with their mineral components. They are commonly preserved through silicification, calcification, dolomitization, opalization, pyritization and sideritization, whereby silicified, calcified and dolomitized coal balls are best preserved (Zheng et al. 2008). Significantly, the number of fossil wood specimens in western Liaoning is very high, and most of them are silicified. Anatomically, the majority of fossil wood specimens from western Liaoning contain well-preserved secondary xylem, and four genera, including Lioxylon Zhang, Wang, Saiki, Li et Zheng, Sahnioxylon Bose et Sah, Sciadopitys-like wood and Sinocycadoxylon Zhang, Yang, Fu, Zheng et Wang, were reported with distinct piths. Lioxylon liaoningense Zhang, Wang, Saiki, Li et Zheng, a structurally preserved cycad stem, has a large pith (Wang et al. 2005;
Zhang et al. 2006). Sahnioxylon rajmahalense (Sahni) Bose et Sah contains heterogeneous pith cells (Zheng et al. 2005). Sciadopitys-like wood, a new fossil wood species, bears a heterogeneous pith consisting of parenchyma cells and small number of scattered sclerenchyma cells (Jiang et al. 2012). Sinocycadoxylon liianum Zhang, Yang, Fu, Zheng et Wang is a polyxylic cycad with a small pith, a polyxylic vascular cylinder and cortex (Zhang et al. 2012).

\subsection{Generic and specific diversity}

Previous studies from the Tiaojishan Formation in western Liaoning documented 12 species of 9 genera of fossil woods, i.e., Lioxylon liaoningense (Zhang et al. 2006), Haplomyeloxylon tiaojishanense Zhang et Wang, Xenoxylon hopeiense Chang, Xenoxylon latiporosum Gothan (Zheng et al. 2008), Sahnioxylon rajmahalense Bose et Sah, Sahnioxylon sp. (Zheng et al. 2005), Pinoxylon dacotense Knowlton, Xenoxylon phyllocladoides Gothan, Araucariopitys sp. (Jiang et al. 2008), Ginkgoxylon liaoningense (Jiang et al. 2016), Sciadopitys-like wood (Jiang et al. 2012) and Sinocycadoxylon liianum (Zhang et al. 2012). However, recent systematic investigations show 
that a high wood diversity on both genera and species levels occurs in the Tiaojishan Formation (Jiang 2012). Among them, 17 genera are assigned to Coniferopsida; one genus to Ginkgopsida, two genera to Cycadopsida and one genus to Gymnospermae incertae sedis, respectively. Thus, the available data so far show that a total of 30 species of 21 genera of fossil wood taxa have been reported in the Tiaojishan Formation in Beipiao area (Table 1).

It is worth noting that some new types of woods occur in this formation. They can be systematically assigned to several genera, i.e., Lioxylon, Taxoxylon, Keteleerioxylon, Protosciadopityoxylon, Sciadopitys-like, Protaxodioxylon and Protocupressinoxylon (Jiang 2012). Detailed descriptions of these taxa will be published separately.

Lioxylon and Sinocycadoxylon are the only two cycad woods found in Beipiao area. Lioxylon is a structurallypreserved stem with a large pith, a xylem cylinder, a cortex and numerous petioles bases. The detailed anatomical evidence indicates that the genus has a close systematic affinity to fossil and living Cycadales and shows distinct anatomical structures from the Bennettitales (Wang et al. 2005; Zhang et al. 2006). Only two species of Lioxylon have been recorded from the Tiaojishan Formation in western Liaoning, including Lioxylon liaoningense (Zhang et al. 2006) and Lioxylon sp. (Jiang 2012). Lioxylon from Beipiao represents the best anatomically-preserved fossil stem of Cycadopsida in Asia.

Fossil wood record of Ginkgopsida is quite rare in western Liaoning. Only one species was reported from the Jurassic of western Liaoning, i.e. Ginkgoxylon liaoningense (Jiang et al. 2016). Due to the scarcity of Ginkgo wood in the Jurassic, Ginkgoxylon liaoningense from western Liaoning may provide a link for the evolutionary history of ginkgoaleans.

Coniferopsida represents the most abundant group of fossil wood in the Tiaojishan Formation in Beipiao area, as about 24 species of 17 genera have been documented (Jiang 2012). Among them, the Coniferales are the most dominant, represented by 19 species of 14 genera in five families, i.e., Araucariaceae, Pinaceae, Sciadopityaceae, Podocarpaceae and Cupressaceae. The Podocarpaceae Family is the second most common group, followed by Taxales. Additionally, five species of three genera of fossil wood are ascribed to incertae sedis of Coniferopsida, which include Xenoxylon, Circoporoxylon and Haplomyeloxylon.

The wood of Gymnospermae incertae sedis is represented by only one genus, Sahnioxylon, in western Liaoning. Sahnioxylon is a form-genus of Mesozoic wood, and its affinity has long been debated as either bennettitalean or angiospermous. Zheng et al. (2005) investigated the fossil wood from western Liaoning and demonstrated that Sahnioxylon is neither bennettitalean nor
Table 1 List of fossil wood taxa identified from the Jurassic Tiaojishan Formation in Beipiao, western Liaoning

\begin{tabular}{|c|c|c|}
\hline \multicolumn{2}{|l|}{ Plant affinity } & \multirow{2}{*}{$\begin{array}{l}\text { Fossil wood species } \\
\text { Lioxylon sp. }\end{array}$} \\
\hline Cycadopisida & Cycadales & \\
\hline & & $\begin{array}{l}\text { Lioxylon liaoningense Zhang, Wang, } \\
\text { Zheng, Saiki et Li }\end{array}$ \\
\hline & & $\begin{array}{l}\text { Sinocycadoxylon liianum Zhang, } \\
\text { Yang, Fu, Zheng et Wang }\end{array}$ \\
\hline Ginkgopsida & Ginkgoales & $\begin{array}{l}\text { Ginkgoxylon liaoningense Jiang, } \\
\text { Wang, Philippe et Wang }\end{array}$ \\
\hline \multirow[t]{25}{*}{ Coniferopsida } & Podocarpales & $\begin{array}{l}\text { Phyllocladoxylon xinqiuensis Cui et } \\
\text { Liu }\end{array}$ \\
\hline & \multirow[t]{4}{*}{ Podocarpaceae } & $\begin{array}{l}\text { Protophyllocladoxylon } \\
\text { franconicum Vogellehner }\end{array}$ \\
\hline & & Podocarpoxylon dacrydioides Cui \\
\hline & & Podocarpoxylon sp. \\
\hline & & $\begin{array}{l}\text { Protopodocarpoxylon batuyingziense } \\
\text { Zheng et Zhang }\end{array}$ \\
\hline & Taxales & Taxoxylon sp. \\
\hline & Taxaceae & \\
\hline & Coniferales & Keteleerioxylon liaoxiense \\
\hline & \multirow[t]{2}{*}{ Pinaceae } & Keteleerioxylon sp. \\
\hline & & Protocedroxylon sp. \\
\hline & \multirow[t]{3}{*}{ Sciadopitysaceae } & $\begin{array}{l}\text { Protosciadopityoxylon liaoningense } \\
\text { Zhang, Zheng et Ding }\end{array}$ \\
\hline & & Protosciadopityoxylon lamayingense \\
\hline & & $\begin{array}{l}\text { Sciadopitys-like wood (Jiang et al. } \\
\text { 2012) }\end{array}$ \\
\hline & \multirow[t]{3}{*}{ Taxodiaceae } & Taxodioxylon szei Yang et Zheng \\
\hline & & Protaxodioxylon romanense Philippe \\
\hline & & Protaxodioxylon zhoui \\
\hline & \multirow[t]{2}{*}{ Cupressaceae } & Protocupressinoxylon tiaojishanense \\
\hline & & $\begin{array}{l}\text { Protocupressinoxylon mishanense } \\
\text { Zheng et Zhang }\end{array}$ \\
\hline & Araucariaaceae & Araucariopitys sp. \\
\hline & Pinoidea & Pinoxylon dacotense Knowlton \\
\hline & \multirow{5}{*}{$\begin{array}{l}\text { Coniferales incertae } \\
\text { sedis }\end{array}$} & Xenoxylon hopeiense Chang \\
\hline & & $\begin{array}{l}\text { Xenoxylon latiporosum } \\
\text { (Gramer) Gothan }\end{array}$ \\
\hline & & Xenoxylon phyllocladoides Gothan \\
\hline & & Circoporoxylon sp. \\
\hline & & $\begin{array}{l}\text { Haplomyeloxylon tiaojishanense } \\
\text { Zhang et Wang }\end{array}$ \\
\hline \multirow{2}{*}{\multicolumn{2}{|c|}{ Gymnosperms incertae sedis }} & $\begin{array}{l}\text { Sahnioxylon rajmahalense (Sahni) } \\
\text { Bose et Sah }\end{array}$ \\
\hline & & Sahnioxylon sp. \\
\hline
\end{tabular}

truly angiospermous. It represents an evolutionary transitional type and a link from the Paleozoic genus Guizhouoxylon, through Late Triassic genus Paradotoxylon, to angiosperms devoid of vessels, and may represent an 
ancestral plant of angiosperms without vessels (Zheng et al. 2005).

It is especially worth noting that fossil Cycadopsida and Ginkgopsida woods are very rare in China. Among these taxa, Ginkgoxylon, Sciadopitys-like wood and Keteleerioxylon are the first to be ascribed from the Jurassic of China. The diversity of the wood taxa in Beipiao of western Liaoning underscores the significance of this fossil wood Lagerstätte in northern China.

\section{Evolutionary implications of major fossil plant groups}

\subsection{Fossil cycad wood}

Cycadales, one of the most ancient groups of seed plants, generally consists of 10 (Eckenwalder 1980) or 11 (Stevenson 1992) living genera, most of which are geographically restricted to tropical and subtropical regions (Zhang et al. 2006). The fossil record of Cycadales dates back 250 million years ago, however, their evolutionary history remains relatively poorly understood (Zhang et al. 2006). Compared with the abundant leaf fossils of cycads, permineralized stems with anatomical structure are rarely reported in China. Lioxylon and Sinocycadoxylon are the only two representative Cycadales that were recorded in the Tiaojishan Formation. Anatomically, Lioxylon shows well-preserved pith, cortex and xylem cylinders, and representing so far one of the most important structurally preserved, monoxylic, cycad-like fossil stem found in China.

The stems of Lioxylon are long and cylindrical to pyriform in shape, and measure up to $20 \mathrm{~cm}$ in diameter. The apical part of the stem is covered with an armor of helically arranged petiolar and cataphyllar bases. Both the pith and cortex are large, consisting of medullary bundles, mucilage sacs, parenchyma, transfusion tissue and sclerotic cells. The pith is surrounded by two sets of xylem cylinders. The inner one is centripetal, and the outer one is centrifugal. The vascular bundles in the petiolar and cataphyllar base consist of two bundle series: one is arranged in an arc along the adaxial margin of petiolar and cataphyllar bases, and the other is a poorly-developed omega-shaped or irregular series, extending from the center to abaxial side (Wang et al. 2005; Zhang et al. 2006).

Lioxylon stems from the Tiaojishan Formation show a close systematic affinity in their anatomy to living cycads. The predominance of bordered pits (araucaroid pitting) in Lioxylon (Fig. 3) suggests a closer relationship with the Cycadales, as the tracheids in most living cycads have multiseriate bordered pits. Only in Zamia and Stangeria the tracheids are scalariform (Greguss 1968). So far, only about 15 genera (including Lioxylon) of fossil cycads with anatomical preserved structures have been reported worldwide (Zhang et al. 2012). These are restricted to North and South America, Antarctica, India, Japan and China. Lioxylon stems also show some differences to those of known fossil cycad genera (Zhang et al. 2006). It is further inferred that Lioxylon may represent a transitional type of stem between Jurassic pteridosperms and Medullosa (cf. Wang et al. 2005; Zhang et al. 2006). Thus, Lioxylon is particularly significant in the evolution of the cycads and provides further evidence for understanding the diversity of cycads during the Mesozoic.

\subsection{Fossil ginkgo wood}

For many years, our knowledge on ginkgoaleans has been obtained mainly from vegetative compressions, such as Baiera Braun, Eretmophyllum Thomas, Ginkgodium Yokoyama, Ginkgoites Seward, Ginkgoitocladus Krassilov, Glossophyllum Krausel, Pseudotorellia Florin and Sphenobaiera Florin (Zhou 1997). Ovulate organs are rare and are represented by Ginkgo yimaensis Zhou, Yimaia hallei Zhou, Karkenia incurve Archangelsky, Karkenia asiatica Krassilov, Karkenia hauptmannii Kirchner and Grenana angrenica Samylina (Archangelsky 1965; Krassilov 1972; Zhou and Zhang 1989, 1992; Samylina 1990; Kirchner and Van Konijnenburg-van Cittert 1994). However, studies on ginkgophyte woods are very limited, and only seven fossil morphogenera have been identified worldwide, including Baieroxylon Greguss, Ginkgoxylon (de Sapota emend. Süß) ex Philippe et Bamford, Ginkgophytoxylon Vozenin-Serra, Broutin et Toutin-Morin, Ginkgomyeloxylon Giraud et Hankel, Ginkgoxylpropinquus Savidge, Primoginkgoxylon Süß et al., Protoginkgoxylon (Khudajberdyev) Zheng et al. (2008) and Palaeoginkgoxylon Feng et al.(2010).

Compared with diverse fossil leaf floras, the Mesozoic ginkgophyte wood records are very limited. Previously, no Jurassic ginkgophyte wood has been described from China. The new fossil wood material of Ginkgoxylon liaoningense from western Liaoning shares numerous similar characters with the genus Ginkgoxylon; but differs from Ginkgo wood in having protopinoid pitting of the radially tracheidal walls (Jiang et al. 2016). Ginkgoxylon also differs from Baieroxylon in having chains of inflated vertical parenchymatous cells and idioblasts (Fig. 4). With Ginkgoxylon liaoningense (Middle to Late Jurassic transition), we now have an ancestral form for a species series, continuing with G. chinense Zhang, Zheng et Shang (Aptian, Early Cretaceous), G. gruettii Pons et Vozenin-Serra (Cenomanian, Late Cretaceous), and Ginkgo beckii Scott, Barghoorn et Prakash (Miocene). Anatomical changes in this series are gradual and mostly limited to the radial pitting becoming more and more abietinean (Jiang et al. 2016).

In China, the previous fossil wood records of Ginkgoales are mainly restricted to the Permian and Cretaceous 

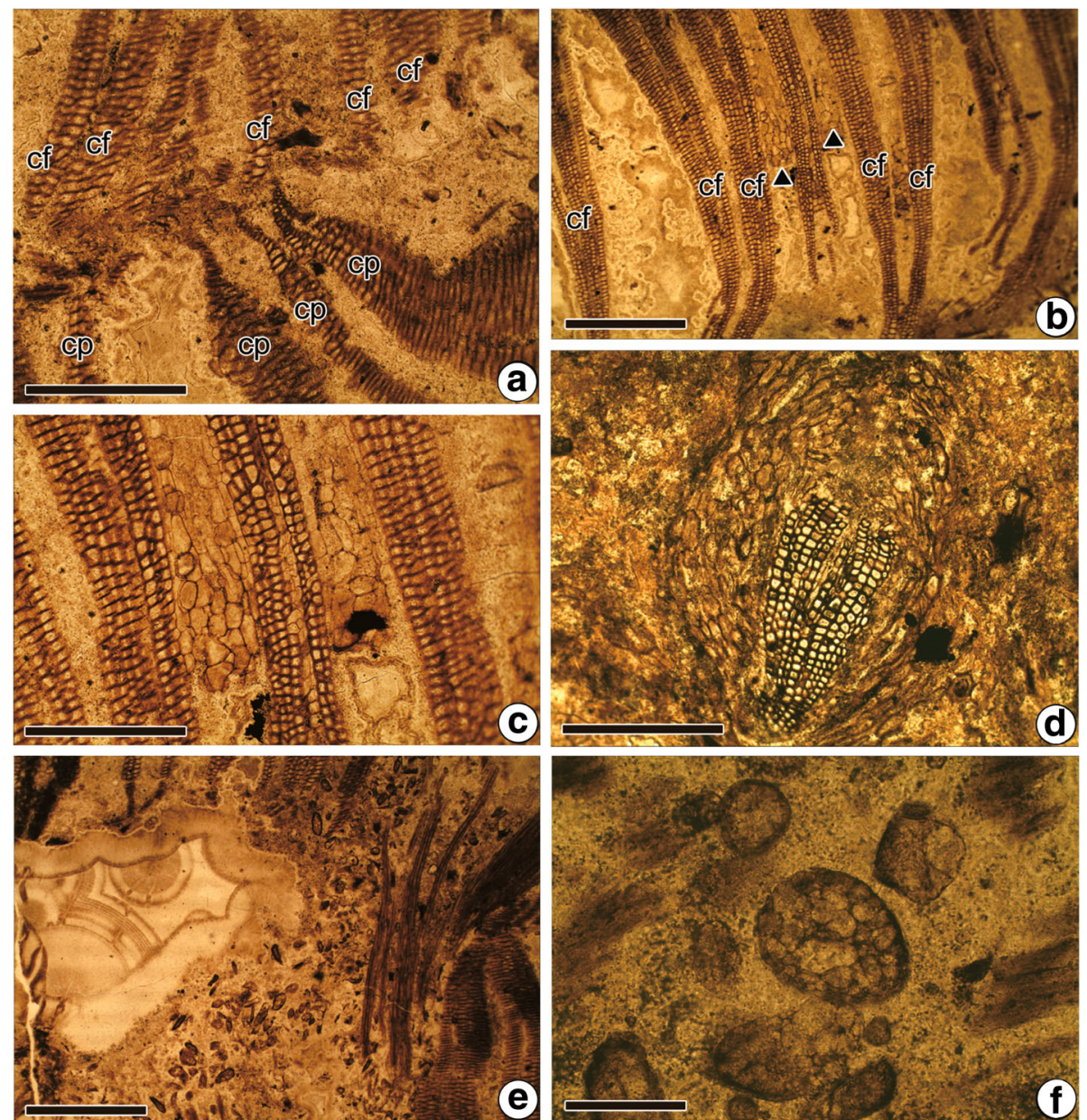

Fig. 3 Lioxylon sp. a Transverse section, showing the centripetal (cp) and centrifugal (cf) xylem cylinders; scale bar = 0.5 mm; b Transverse section, showing the polygonal pith cells (arrows) between centrifugal (cf) xylem strands; scale bar $=1.0 \mathrm{~mm}$; c Enlargement of $\mathbf{b}$, showing details of the pith cells; scale bar $=0.5 \mathrm{~mm}$; $\mathbf{d}$ Transverse section of the pith, showing a medullary bundle; scale bar $=0.5 \mathrm{~mm}$; e Transverse section of the pith, showing scattered transfusion cells; scale bar $=1.0 \mathrm{~mm}$; $\mathbf{f}$ Enlargement of $\mathbf{e}$, showing details of the transfusion cells with large and small simple pits; scale bar $=100 \mu \mathrm{m}$

periods (Zhang et al. 2000b; Zheng and Zhang 2000; Feng et al. 2010). The fossil records of the Jurassic Ginkgoxylon in the Tiaojishan Formation in Beipiao thus provide a link between the Permian and Cretaceous in the view of the evolution of Ginkgoales. The xylem structure of Ginkgoxylon liaoningense illustrates the basal state of Ginkgo wood anatomy (Jiang et al. 2016), and displays several Ginkgo features, including inflated axial parenchyma and intrusive tracheid tips. Because it is slightly younger than the oldest recorded Ginkgo reproductive organs (the Yima Formation, $170 \mathrm{Ma}$ ), this fossil wood very probably represents the oldest bona fide fossil Ginkgo wood and the missing ancestral form of Ginkgo wood evolution (Jiang et al. 2016).

\subsection{Fossil conifer wood}

Conifer is the dominant group of the permineralized woods in the Tiaojishan Formation. Sciadopitys, a living monotypic genus (S. verticillata (Thunb.) Sieb. et Zucc) of the family Sciadopityaceae, is always considered as a relic plant endemic to Japan, though it has been cultivated in other parts of the world (Wu et al. 1996). Although the extant Sciadopitys is extremely limited in its current distribution, it occurs widely in the Cenozoic record in the form of fossil leaves, seed cones and wood (Menzel 1913; Christophel 1973; Sveshnikova 1981; Manum 1987; Bose and Manum 1990, 1991; Ohsawa et al. 1991; Florin 1922a, b; Saiki 1992; Mosbrugger et al. 1994). The unique structures of living Sciadopitys that differentiate this genus from other conifers are the sub-taxodioid cross-field pits with an extended pit aperture, and the window-like cross-field pits (Zhou and Jiang 1994; Jiang et al. 2010b). In contrast, the anatomical structure of Sciadopitys-like fossil xylem is rarely documented. A new Sciadopitys-like wood was found in the Tiaojishan Formation (Jiang et al. 2012). From a palaeobiogeographic point of view, although the extant 

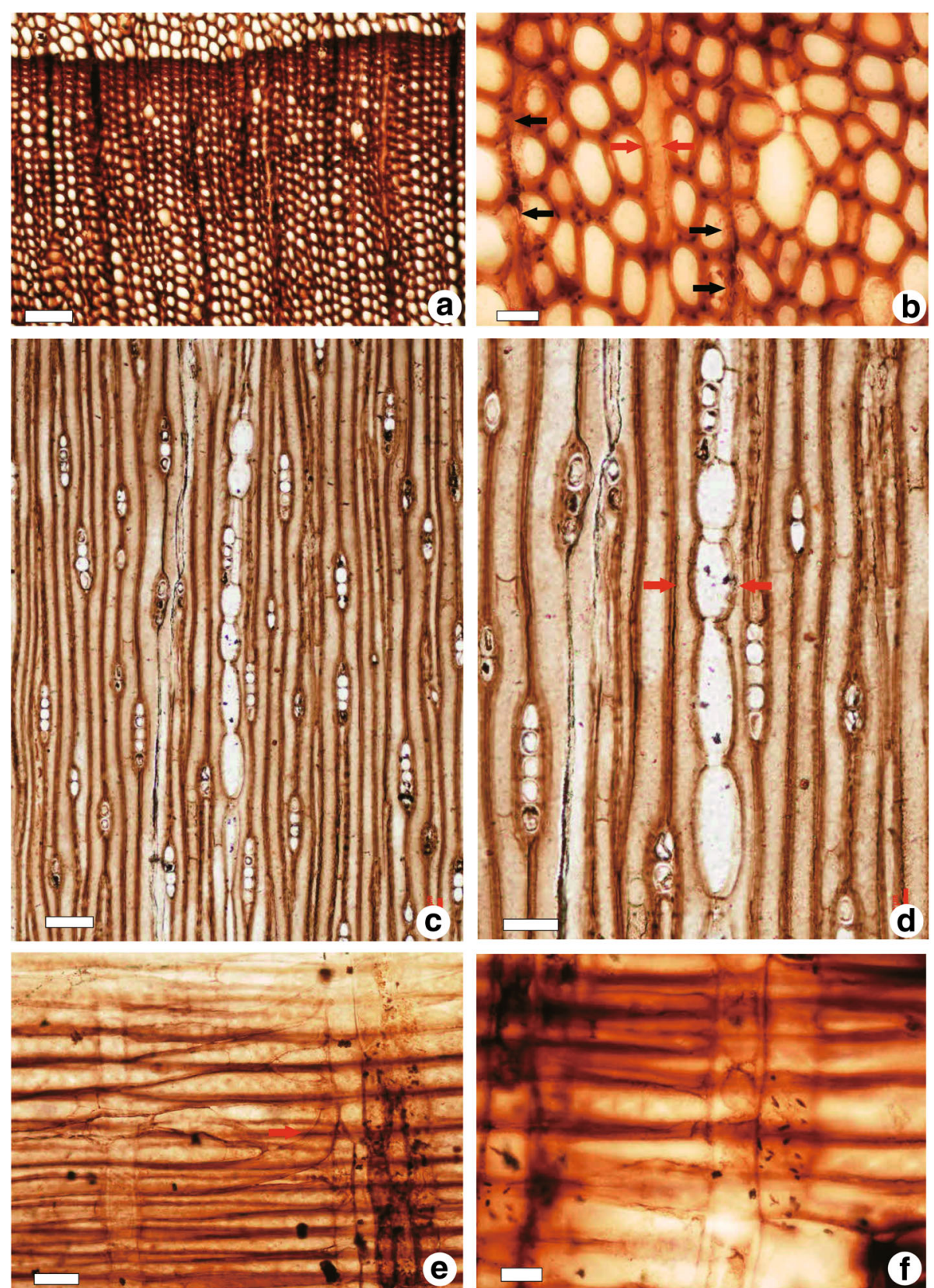

Fig. 4 Ginkgoxylon liaoningense Jiang, Wang, Philippe et Zhang. a Transverse section with a well-marked growth ring. Scale bar = $100 \mu m$; $\mathbf{b}$ Transverse section with intercellular spaces (red arrows) and locally destroyed walls (black arrows), possibly resulting from a fungal attack. Scale bar $=40 \mu \mathrm{m}$; c Tangential section; note the tracheid tip contiguous to the ray margin. Scale bar $=100 \mu \mathrm{m}$; $\mathbf{d}$ Tangential section with inflated axial parenchyma associated to a ray (red arrow). Scale bar $=60 \mu \mathrm{m}$; e Radial section with a tracheid bunch (red arrow) with tips bent alongside wood rays. Scale bar $=40 \mu \mathrm{m} ; \mathbf{f}$ Radial section with cross-fields. Note that the cross-fields are $2-4$ cupressoid oculipores, with an oblique aperture. Scale bar $=20 \mu \mathrm{m}$ (after Jiang et al. 2016)

Sciadopitys is endemic to Japan, its ancestors may have existed in China during the Early and Middle Jurassic, flourished in the Jurassic and Cretaceous, and may have migrated from China to western Europe and northwestern Canada. Since the Cretaceous, due to considerable changes in palaeoclimate and palaeoenvironment, sciadopityaceous conifers became extinct in China, Europe and North America, but still survived in Japan (Farjon 2005).

The earliest fossil record of Keteleerioxylon has been reported from the Early Cretaceous of Franz Josef Land in Russia (Shilkina 1960). However, the occurrence of fossil wood Keteleerioxylon in the Tiaojishan Formation indicates that this morphogenus might have originated 
in China. The occurrence of Keteleerioxylon fossil wood from western Liaoning extends the age of its first appearance back to the Jurassic, which shows great significance for the origin and evolution of Keteleeria. Furthermore, our fossil wood studies show that the occurrence of Taxodioxylon (Fig. 5) and Taxoxylon in western Liaoning also represents their first record in the Jurassic in China. This implies that the age of the fossil records has been pushed back to the Jurassic, which helps us to re-examine the evolution of these two groups.

The above analysis demonstrates that fossil wood with well-preserved anatomical structures in the Jurassic of western Liaoning shows systematic affinities with closely related living taxa. Thus they provide evidence for exploring the origin, development and evolution of the Yanliao Flora, as well as its radiation and evolution of plants before the development of the Cretaceous Jehol Biota.

\section{Palaeoclimatic implications}

Fossil wood is one of the significant proxies for terrestrial palaeoclimate and reconstruction in Earth history (Jiang 2012). In particular, growth ring data are distinct characters which provide information for palaeoclimatic conditions in the Middle to Late Jurassic transition in western Liaoning. In order to reveal the palaeoclimate variations, we calculated the Annual Mean Sensitivity (AS), Mean Sensitivity (MS) and Early/Late growth ring ratio of the growth rings of fossil wood material. AS analysis indicates that the water supply shows significant seasonal changes with dry and wet seasons within 1 year during the Middle-Late Jurassic episodes in Beipiao area of western Liaoning. Reconstructions of the height of
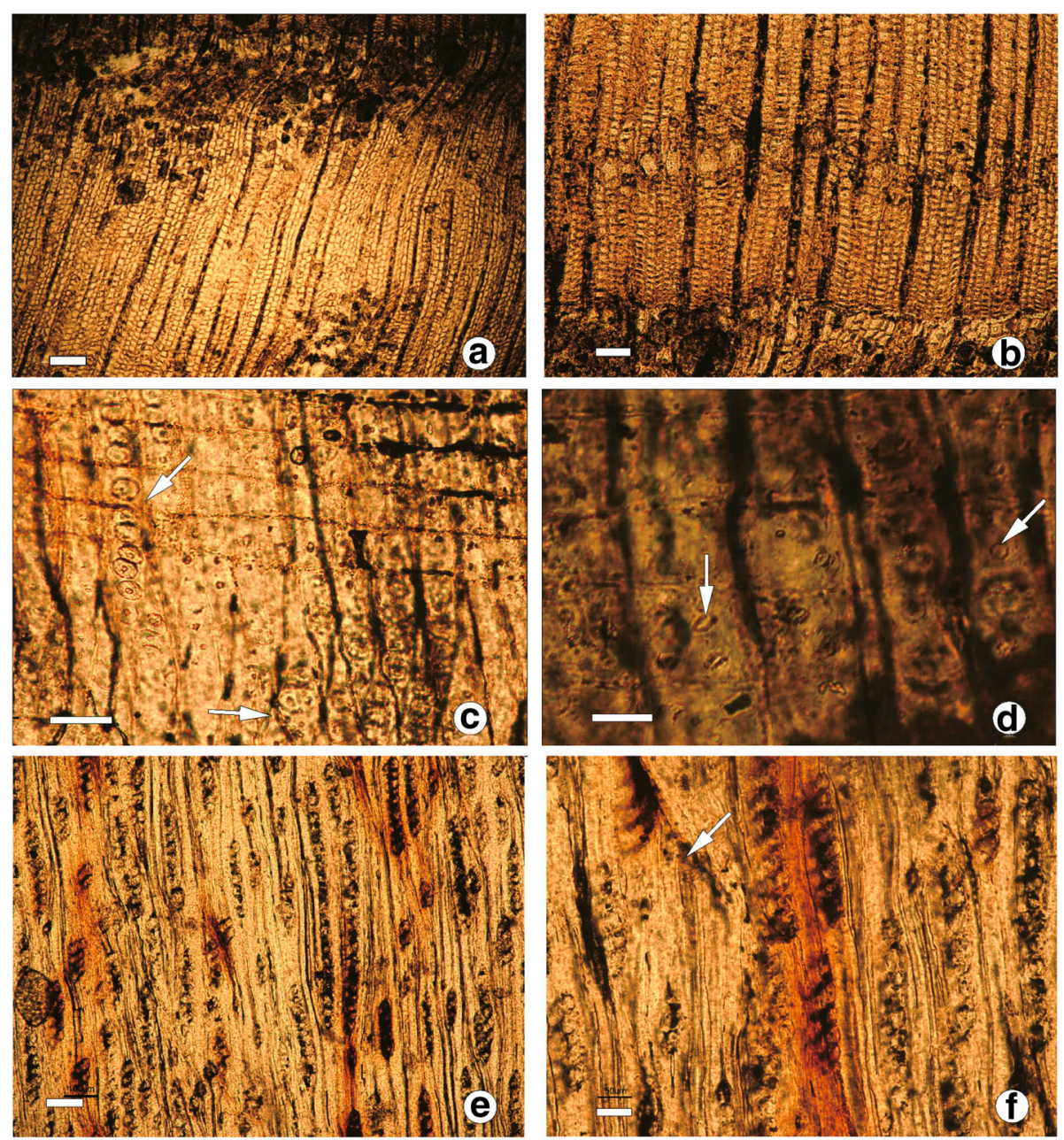

Fig. 5 Taxodioxylon szei Yang et Zheng. a Transverse section with growth ring. Scale bar $=200 \mu m$; b Transverse section with traumatic resin canals. Scale bar $=100 \mu \mathrm{m}$; c Radial section with radial wall pits, uniseriate, round and separate (upper arrow); Biseriate, alternate or opposite (lower arrow). Scale bar $=50 \mu \mathrm{m}$; d Radial section with cross-fields, taxodioid, pit and cupressoid pit (arrow). Scale bar = $20 \mu \mathrm{m}$; e Tangential section with xylem rays. Scale bar $=100 \mu \mathrm{m} ; \mathbf{f}$ Tangential section with idioblast on xylem rays (arrow). Scale bar $=50 \mu \mathrm{m}$ 
fossil coniferous trees were made using the Niklas (1994) and Mosbrugger et al. (1994) approaches; and the average height of the coniferous trees in this episode is about $25 \mathrm{~m}$. The palaeoclimate of the Middle-Late Jurassic of the Beipiao area was a monsoonal climate with cool, dry winter and warm, wet summer (Wang et al. 2006; 2009; Jiang 2012). The general palaeoclimate was temperate to subtropical during the Middle-Late Jurassic transition and it was suitable for forest growth and development. In addition, analyses of some special anatomical structures of the wood material, such as false rings, traumatic resin canals, twisted growth rings, and wormholes, reveal particular implications of the palaeoclimate and palaeoenvironment. Although the palaeoclimate in the Middle-Late Jurassic in Beipiao was favourable for tree growth, some fluctuations and severe disturbances also occurred, including low temperature, heavy wind, volcanic eruptions, frost and other abnormal conditions (Jiang 2012; Jiang et al. 2016).

In western Liaoning, some climate-sensitive wood taxa also provided information for climate cooling events. In Beipiao area, a variety of Xenoxylon were documented in the Middle to Late Jurassic transition. Xenoxylon has a typical circumpolar distribution (in the broad sense) with the majority data from high palaeolatitudes (Philippe and Thévenard 1996; Philippe et al. 2009). The European Cretaceous data suggested that the mean annual palaeotemperature at the localities where Xenoxylon occurs was generally below $15^{\circ} \mathrm{C}$, thus the genus Xenoxylon was bound to cool and/or wet climate conditions (Philippe and Thévenard 1996; Philippe et al. 2009). Clearly, the occurrence of various species of Xenoxylon in the Tiaojishan Formation might indicate a short-term cooling event whereas a warm and wet climate largely prevailed in the western Liaoning during the Middle to Late Jurassic transition.

\section{Conclusions}

1) The Tiaojishan Formation in Beipiao, western Liaoning, generates in the area a valuable, wellpreserved, fossil Lagerstätte including various fossil plants, permineralized fern rhizomes and fossil woods.

2) 30 species of 21 genera of gymnospermous woods have been recorded from the Tiaojishan Formation in Beipiao, which represents the most distinctive and productive area with a high diversity of fossil woods in China.

3) The permineralized wood palaeoflora in the Tiaojishan Formation is dominated by Coniferopsida, followed by Cycadopsida and Ginkgopsida.

4) The permineralized palaeoflora with well-preserved anatomy from the Tiaojishan Formation provides significant evidence for understanding the evolution of the major gymnosperm plant groups, including cycads, ginkgoaleans as well as Sciadopitys-like conifers.

5) The taxonomic diversity of the Tiaojishan Formation in Beipiao shows the great importance of the species diversity of the Yanliao Flora, as well as the radiation and evolution of plants before the Early Cretaceous Jehol Biota.

6) The palaeoclimate of the Middle-Late Jurassic of the Beipiao area was characterized by seasonal variations and some cool climate events under the temperate to subtropical type climate conditions.

\section{Abbreviations}

AS: Annual Mean Sensitivity; Ms: Mean Sensitivity

\section{Acknowledgements}

We are grateful to Prof. Zhi-Yan Zhou (Nanjing) and Dr. Marc Philippe (Lyon) for providing references and suggestions, and to Dr. Carole Gee for improvements to the English. Special appreciations are due to Dr. Yi Zhang (Shenyang) for help with photographs. We also appreciate Prof. Cheng-Sen Li and Prof. Marion Bamford for carefully reviewing the manuscripts and made helpful comments and suggestion. Yong-Dong Wang acknowledges grants from the Strategic Priority Program (B) of CAS (Grant Nos. XDB 18000000 and 26000000), National Natural Sciences Foundation of China (Grant Nos. 41709464 and 41688103) and State Key Program for Basic Research and Development of Ministry of Science and Technology of China (Grant No. 2016YSC0600406). Zi-Kun Jiang acknowledges grants from National Natural Sciences Foundation of China (Grant Nos. 41772023 and 41402004) and State Key Laboratory of Palaeobiology and Stratigraphy (Nanjing Institute of Geology and Palaeontology, CAS) (Grant No. 173113). Ning Tian acknowledges the grant of National Natural Sciences Foundation of China (Grant No. 41302004).

\section{Authors' contributions}

ZKJ, YDW, NT, AWX and WZ carried out the fossil wood diversity and evolutionary implications of major fossil plant groups studies. ZKJ, YDW, LQL and $\mathrm{MH}$ participated in the palaeoclimate implications study. ZKJ, YDW, AWX and $\mathrm{MH}$ helped to draft the manuscript. All authors read and approved the final manuscript.

\section{Competing interests}

The authors declare that they have no competing interests.

\section{Publisher's Note}

Springer Nature remains neutral with regard to jurisdictional claims in published maps and institutional affiliations.

\section{Author details}

${ }^{1}$ Chinese Academy of Geological Sciences, Beijing 100037, China. ${ }^{2}$ State Key Laboratory of Palaeobiology and Stratigraphy, Nanjing Institute of Geology and Palaeontology, Chinese Academy of Sciences, Nanjing 210008, Jiangsu Province, China. ${ }^{3}$ Center for Excellence in Life and Palaeoenvironment, Chinese Academy of Sciences, Nanjing 210008, Jiangsu Province, China. ${ }^{4}$ College of Palaeontology, Shenyang Normal University, Shenyang 110034, Liaoning Province, China. ${ }^{5}$ Key Laboratory for Evolution of Past Life in Northeast Asia, Ministry of Land and Resources, Shenyang 110034, Liaoning Province, China. ${ }^{6}$ University of Chinese Academy of Sciences, Beijing 100049, China. ${ }^{7}$ Shenyang Institute of Geology and Mineral Resources, Shenyang 110034, Liaoning Province, China.

Received: 6 April 2018 Accepted: 25 June 2018

Published online: 08 January 2019

\section{References}

Archangelsky, S.A. 1965. Fossil Ginkgoales from the Tico flora, Santa Cruz Province, Argentina. Bulletin of the British Museum (Natural History). Geology 10: $121-137$. 
Bamford, M., and M. Philippe. 2001. Gondwanan Jurassic-early cretaceous homoxylous woods: A nomenclatural revision of the genera with taxonomical notes. Review of Palaeobotany and Palynology 113: 287-289.

Bose, M.N., and S.B. Manum. 1990. Mesozoic conifer leaves with 'Sciadopitys-like' stomatal distribution. A re-evaluation based on fossils from Spitsbergen, Greenland and Baffin Island. Norsk Polarinstitutt Skrifter 192: 1-81.

Bose, M.N., and S.B. Manum. 1991. Additions to the family Miroviaceae (Coniferae) from the lower cretaceous of West Greenland and Germany: Mirovia groenlandica n. sp., Triaenia crassa (Seward) comb. nov., and Tritaenia linkii Mädefrau et Rudolph emend. Polar Research 9 (1): 9-20.

Chang, C.Y. 1929. A new Xenoxylon from North China. Bulletin of the Geological Society of China 8 (3): 243-261.

Chang, S.C., H.C. Zhang, P.R. Renne, and Y. Fang. 2009. High-precision ${ }^{40} \mathrm{Ar} /{ }^{39} \mathrm{Ar}$ age constraints on the basal Lanqi formation and its implications for the origin of angiosperm plants. Earth and Planetary Sciences Letters 279 (3-4): 212-221.

Cheng, Y.M. 2011. A new species of Ashicaulis (Osmundaceae) from the Mesozoic of China: A close relative of living Osmunda claytoniana L. Review of Palaeobotany and Palynology 165: 96-102.

Cheng, Y.M., and C.S. Li. 2007. A new species of Millerocaulis (Osmundaceae, Filicales) from the middle Jurassic of China. Review of Palaeobotany and Palynology 144 (3-4): 249-259.

Cheng, Y.M., Y.F. Wang, and C.S. Li. 2007. A new species of Millerocaulis (Osmundaceae) from the middle Jurassic of China and its implication for evolution of Osmunda. International Journal of Plant Sciences 168 1351-1358.

Christophel, D.C. 1973. Sciadopitophyllum canadense gen. et sp. nov:: A new conifer from western Alberta. American Journal of Botany 60: 61-66.

Ding, Q.H., N. Tian, Y.D. Wang, Z.K. Jiang, S.W. Chen, D. Wang, W. Zhang, S.L. Zheng, A.W. Xie, G.Q. Zhang, and Z.J. Liu. 2016. Fossil coniferous wood from the early cretaceous Jehol biota in western Liaoning, NE China: New material and palaeoclimate implications. Cretaceous Research 61: 57-70.

Ding, Q.H., S.L. Zheng, and W. Zhang. 2000. Mesozoic fossil woods of genus Xenoxylon from Northeast China and its palaeoecology. Acta Palaeontologica Sinica 39 (2): 237-249 (in Chinese with English abstract).

Du, N.Z. 1982. Two fossil woods from Heilongjiang sheng of China. Acta Botanica Sinica 24 (4): 383-387.

Duan, S.Y. 2000. Several fossil woods from Mesozoic of western Liaoning Province, Northeast China. Acta Botanica Sinica 42 (2): 207-213 (in Chinese with English abstract).

Duan, Y., S.L. Zheng, D.Y. Hu, L.J. Zhang, and W.L. Wang. 2009. Preliminary report on middle Jurassic strata and fossils from Linglongta area of Jianchang, Liaoning. Global Geology 28 (2): 143-147.

Eckenwalder, J.E. 1980. Taxonomy of the West India cycads. Journal of the Arnold Arboretum 61 (4): 701-722.

Farjon, A. 2005. A monograph of Cupressaceae and Sciadopitys. England: Royal Botanic Gardens, Kew.

Feng, Z., J. Wang, and R. Rößler. 2010. Palaeoginkgoxylon zhoui, a new ginkgophyte wood from the Guadalupian (Permian) of China and its evolutionary implications. Review of Palaeobotany and Palynology 162 (2): 146-158.

Florin, R. 1922a. On the geological history of the Sciadopitineae. Svensk Botanisk Tidskrift 16: 260-270.

Florin, R. 1922b. Über das Vorkommen von Sciadopital im deustchen Tertiar. Senckenbergiana 4 (1-2): 1-5.

Gothan, W. 1905. Zur Anatomie lebender und fossiler Gymnospermen-Hölzer. Abhandlungen Preussische Geologische Landesanst 44: 1-108.

Gothan W. Fossile Hölzer aus dem Bathonian von Russisch-Polen[J]. Verhandlungen Russische-Kaiserlische Mineralogische Gesellschaft, 1906, 44: 435-458.

Gothan W. Die fossilen Hölzer von König Karls Land[M]. Almqvist \& Wiksell, 1907.

Gothan W. Die fossilen Holzreste von Spitzbergen, von W. Gothan,..[M]. Almqvist och Wiksells boktryckeri, 1910.

Gothan, W., and H.C. Sze. 1933. Über fossile Holzer aus China. Memoirs of National Research Institute of Geology, Academia Sinica 13: 87-104.

Greguss, P. 1968. Xylotomy of the Living Cycads with a Description of Their Leaves and Epidermis. Akademiai Kiado, Budapest.

Hsü, J. 1950a. Brachyoxylon sahnii, a new species of coniferous wood from shantung. Journal of Indian Botanical Society 29 (1): 25-26.

Hsü, J. 1950b. Two coniferous woods, Xenoxylon and Cupressinoxylon from South Hunan. Journal of Indian Botanical Society 29 (1): 24.

Hsü, J. 1950c. Xenoxylon phyllocladoides Gothan from Sinkiang. Journal of Indian Botanical Society 29 (1): 23.
Hsü, J. 1953. On the occurrence of a fossil wood in association with fungous hyphae from Chimo of Est Shantung. Acta Palaeontologica Sinica 1 (2): 80-86 (in Chinese and English).

Jiang, B.Y., X.G. Yao, Y.Z. Niu, X. Rao, and Q.J. Li. 2010a. Outline of the Jurassic and Cretaceous systems in western Liaoning, NE China, 1-84. Hefei: University of Science and Technology of China Press (in Chinese).

Jiang, H.E., D.K. Ferguson, C.S. Li, and Y.M. Cheng. 2008. Fossil coniferous wood from the middle Jurassic of Liaoning Province, China. Review of Palaeobotany and Palynology 150 (1): 37-47.

Jiang, X.M., Y.M. Cheng, and Y.F. Yin. 2010b. Atlas of gymnosperms woods of China, 1-490. Beijing: Science Press (in Chinese).

Jiang, Z.K. 2012. Investigations on the Fossil Wood from the Middle Jurassic in Beipiao of Western Liaoning: Systematic, Diversity, Palaeoclimate and TempoSpatial Distribution [doctoral dissertation]. Chinese Academy of Sciences, pp. 1-221 (in Chinese with English abstract).

Jiang, Z.K., Y.D. Wang, N. Tian, W. Zhang, and S.L. Zheng. 2016. Palaeoclimate and palaeoenvironment implications of the middle-late Jurassic Tiaojishan formation, western Liaoning Province: Evidence form fossil wood data. Acta Geologica Sinica 90 (8): 1669-1678.

Jiang, Z.K., Y.D. Wang, S.L. Zheng, W. Zhang, and N. Tian. 2012. Occurrence of Sciadopitys-like fossil wood (Coniferales) in the Jurassic of western Liaoning and its evolutionary implications. Chinese Science Bulletin 57 (6): 569-572.

Jones, T.P., and N.P. Rowe. 1999. Fossil Plants and Spores: Modern Techniques. London: Geological Society of London.

Kirchner, M., and J.H.A. Van Konijnenburg-van Cittert. 1994. Schmeissneria microstachys (Prel, 1833) Kirchner et Van Konijnenburg-Van Cittert, comb. nov. and Karkenia haupymannii Kirchner et Van Konijnenburg-Van Cittert, sp. nov., plants with ginkgoalean affinities from the Liassic of Germany. Review of Palaeobotany and Palynology 83 (1): 199-215

Krassilov, V.A. 1972. Mesozoic Flora from the Bureja River Basin (Ginkgoales and Czekanowskiales), 1-152. Moscow: Nauka (in Russian).

Manum, S.B. 1987. Mesozoic Sciadopitys-like leaves with observations on four species from the Jurassic of Andøya, northern Norway, and emendation of Sciadopityoides sveshnikova. Review of Palaeobotany and Palynology 51 (1): $145-168$

Mathews, G.B. 1943. A fossil dipterid found near Peking. Geobiologia 1 (1): 50-52.

Matsumoto, M., K. Saiki, W. Zhang, S.L. Zheng, and Y.D. Wang. 2006. A new species of osmundaceous fern rhizome, Ashicaulis macromedullosus sp. nov., from the Middle Jurassic, northern China. Paleontological Research 10 (3): 195-205.

Menzel, P. 1913. Beitrag zur Flora der niederrheinischen Baunkohlen-formation. Berlin Jahrbuch der Königlichen Preußischen Geologischen Landesanstalt 34: 1-98.

Mosbrugger, V., C.T. Gee, G. Belz, and A.R. Ashraf. 1994. Three-dimensional reconstruction of an in-situ Miocene peat forest from the lower Rhine embayment, northwestern Germany - New methods in palaeovegetation analysis. Palaeogeography, Palaeoclimatology, Palaeoecology 110 (3-4): 295-317.

Niklas, K.J. 1994. Plant Allometry: The scaling of form and process, 1-395. Chicago: The University of Chicago Press.

Ogura, Y. 1944. Notes on fossil woods from Japan and Manchoukuo. Japanese Journal of Botany 13: 345-365.

Ohsawa, T., M. Nishida, and H. Nishida. 1991. Structure and affinities of the petrified plants from the cretaceous of northern Japan and Saghalien. IX. A petrified cone of Sciadopitys from the Upper Cretaceous of Hokkaido. Journal of Phytogeography and Taxonomy 39: 97-105.

Philippe, M. 1993. Nomenclature générique des trachéidoxyles mésozoïques à champs araucarioïdes. Taxon 42: 74-80.

Philippe, M., and M. Bamford. 2008. A key to morphogenera used for Mesozoic conifer-like woods. Review of Palaeobotany and Palynology 148: 184-207.

Philippe, M., H.E. Jiang, K. Kim, C. Oh, D. Gromyko, M. Harland, I.-S. Paik, and F. Thévenard. 2009. Structure and diversity of the Mesozoic wood genus Xenoxylon in Far East Asia: Implications for terrestrial palaeoclimates. Lethaia 42 (4): 393-406.

Philippe, M., and F. Thévenard. 1996. Distribution and palaeoecology of the Mesozoic wood genus Xenoxylon: Palaeoclimatological implications for the Jurassic of Western Europe. Review of Palaeobotany and Palynology 91 (1): 353-370

Saiki, K. 1992. A new sciadopityaceous seed cone from the upper cretaceous of Hokkaido, Japan. American Journal of Botany 79 (9): 989-995.

Samylina, V.A. 1990. Grenana - A new genus of seed ferns from the Jurassic deposits of Middle Asia. Botanicheskii Zhurnal 75: 846-850 (in Russian).

Shilkina, I.A. 1960. Wood of a new conifer genus and species from the lower cretaceous deposits of Franz Josef Land. Paläontologische Zeitschrift 1: 113-117. 
Shimakura, M. 1933. Notes on fossil woods, I. Journal of the Geological Society of Japan 40: 475-477 (in Japanese).

Shimakura, M. 1936. Studies on fossil woods from Japan and adjacent lands, contribution I. Science Reports of the Tohoku Imperial University 18: 267-310.

Shimakura, M. 1937. Studies on fossil woods from Japan and adjacent lands, contribution II. Science Reports of the Tohoku Imperial University 19: 1-73.

Stevenson, D.W. 1992. A formal classification of the extant cycads. Brittonia 44 (2): 220-223.

Sveshnikova, I.N. 1981. New fossil genus Sciadopityoides (Pinopsida). Botanicheskii Zhurnal 66: 1721-1729 (in Russian).

Sze, H.C. 1951. Petrified wood from northern Manchuria. Science Record 4 (4): 443-457 (in Chinese with English abstract).

Sze, H.C. 1952. A petrified wood from northern Shensi, with special reference to the age of the Shihchienfeng series in North China. Science Record 5 (1-4): 171-182 (in Chinese).

Sze, H.C. 1953. Atlas of the Paleozoic plants from China. Beijing: Chinese. Academy of Sciences: 1-148 (in Chinese).

Sze, H.C. 1954. On the structure and relationship of Phoroxylon scalariforme Sze. Science China 4: 527-539 (in Chinese with English summary).

Sze, H.C. 1962. A petrified wood from Inner Mongolia. Acta Palaeontologica Sinica 10 (4): 415-423 (in Chinese with English abstract).

Sze, H.C., and H.H. Lee. 1963. Fossil plants of China. Mesozoic plants from China. Vol. 2, 1-429. Beijing: Science Press (in Chinese).

Tian, N., Y.D. Wang, M. Philippe, W. Zhang, Z.K. Jiang, and L.Q. Li. 2014b. A specialized new species of Ashicaulis (Osmundaceae, Filicales) from the Jurassic of Liaoning, NE China. Journal of Plant Research 127 (2): 209-219.

Tian, N., Y.D. Wang, W. Zhang, and Z.K. Jiang. 2014a. A new structurally preserved fern rhizome of Osmundaceae (Filicales) Ashicaulis wangii sp. nov. from the Jurassic of western Liaoning and its significances for palaeobiogeography and evolution. Science China Earth Sciences 57 (4): 671-681.

Tian, N., Y.D. Wang, W. Zhang, Z.K. Jiang, and D.L. Dilcher. 2013. Ashicaulis beipiaoensis sp. nov., a new osmundaceous fern species from the Middle Jurassic of Liaoning Province, northeastern China. International Journal of Plant Sciences 174 (3): 328-339.

Wang, Y.D., K. Saiki, W. Zhang, and S.L. Zheng. 2006. Biodiversity and palaeoclimate of the middle Jurassic floras from the Tiaojishan formation in western Liaoning, China. Progress in Natural Science 16: 222-230.

Wang, Y.D., X.J. Yang, W. Zhang, S.L. Zheng, and N. Tian. 2009. Biodiversity and palaeoclimatic implications of fossil wood from the non-marine Jurassic of China. Episodes 32 (1): 13-20.

Wang, Y.D., W. Zhang, S.L. Zheng, K. Saiki, and N. Li. 2005. New discovery of fossil cycad-like plants from the middle Jurassic of West Liaoning, China. Chinese Science Bulletin 50 (16): 1804-1807.

Wu, H., Y.L. He, and Z.H. Hu. 1996. The development of the cortical resin ducts in the stem of Sciadopitys verticillata. Journal of Northwest University (Natural Science Edition) 26 (6): 529-532 (in Chinese with English abstract).

Xu, K., J.G. Yang, M.G. Tao, and H.D. Liang. 2003. Jurassic system in the north of China. vol. VII. The Stratigraphic Region of Northeast China, 1-261. Beijing: Petroleum Industry Press (in Chinese).

Yang, X.J., W. Zhang, and S.L. Zheng. 2010. An osmundaceous rhizome with sterile and fertile fronds and in situ spores from the Jurassic of western Liaoning. Chinese Science Bulletin 55 (34): 3864-3867.

Zhang, W., Y.D. Wang, K. Saiki, N. Li, and S.L. Zheng. 2006. A structurally preserved cycad-like stem, Lioxylon liaoningense gen. Et. Sp. nov., from the Middle Jurassic in Western Liaoning, China. Progress in Natural Science 16 (sp): 236-248.

Zhang, W., X.J. Yang, X.P. Fu, S.L. Zheng, and Y.D. Wang. 2012. A polyxylic cycad trunk from the middle Jurassic of western Liaoning. China, and its evolutionary implications. Review of Palaeobotany and Palynology 183: 50-60.

Zhang, W., and S.L. Zheng. 1987. Early Mesozoic fossil plants in western Liaoning, Northeast China. In Mesozoic stratigraphy and Palaeontology of Western Liaoning, ed. X.H. Yu, vol. 3, 239-338. Beijing: Geological Publishing House (in Chinese).

Zhang, W., and S.L. Zheng. 1991. A new species of osmundaceous rhizome from Middle Jurassic of Liaoning, China. Acta Palaeontologica Sinica 30 (6): 714 727 (in Chinese with English abstract).

Zhang, W., S.L. Zheng, and Q.H. Ding. 2000a. Early Jurassic coniferous woods from Liaoning, China. Liaoning Geology 17 (2): 88-100 (in Chinese with English abstract).

Zhang, W., S.L. Zheng, and P. Shang. 2000b. A new species of ginkgoalean wood (Ginkgoxylon chinense Zhang et Zheng sp. nov.) from lower cretaceous of Liaoning, China. Acta Palaeontologica Sinica 39 (Supplement): 220-225 (in Chinese with English abstract).
Zheng, S.L. 2004. Biostratigraphy and biota of Tuchengzi age - 1.2.2.6 plants. In Standard sections of Tuchengzi stage and Yixian stage and their stratigraphy, Palaeontology and tectonic-volcanic actions, ed. W.L. Wang, 49-50. Beijing: Geological Publishing House (in Chinese).

Zheng, S.L., Y. Li, W. Zhang, N. Li, Y.D. Wang, X.J. Yang, T.M. Yi, J.. Yang, and X.P. Fu. 2008. Fossil woods of China, 1-356. Beijing: China Forestry Publishing House.

Zheng, S.L., Y. Li, W. Zhang, Y.D. Wang, X.J. Yang, N. Li, and X.P. Fu. 2005. Jurassic fossil wood of Sahnioxylon from western Liaoning, China and special references to its systematic affinity. Global Geology 24 (3): 209-218.

Zheng, S.L., and W. Zhang. 1982. New material of middle Jurassic plant fossils from western Liaoning and their stratigraphical significances. In Bulletin of Shenyang institute of geology and mineral resources, Chinese academy of geological sciences, vol. 4, 160-168.

Zheng, S.L., and W. Zhang. 2000. Late Paleozoic ginkgoalean woods from northern China. Acta Palaeontologica Sinica 39 (Supplement): 119-126.

Zheng, S.L., W. Zhang, and Q.H. Ding. 2001. Discovery of fossil plants from middle-upper Jurassic Tuchengzi formation in western Liaoning, China. Acta Palaeontologica Sinica 40 (1): 67-85 (in Chinese with English abstract).

Zhou, Y., and X.M. Jiang. 1994. Wood anatomy and ultrastructure of Gymnospermous woods in China, 1-632. Beijing: China Forestry Publishing House (in Chinese).

Zhou, Z.Y. 1997. Mesozoic ginkgoalean megafossils: A systematic review. In Ginkgo biloba: A global treasure from biology to medicine, ed. T. Hori, 183-206. Tokyo: Springer Verlag.

Zhou, Z.Y., and B.L. Zhang. 1989. A Middle Jurassic Ginkgo with ovule-bearing organs from Henan, China. Palaeontographica Abteilung B: Palaeophytologie 221: 113-133.

Zhou, Z.Y., and B.L. Zhang. 1992. Baiera hallei Sze and associated ovule-bearing organs from the middle Jurassic of Henan, China. Palaeontographica Abteilung B: Palaeophytologie 224: 151-169.

\section{Submit your manuscript to a SpringerOpen ${ }^{\circ}$ journal and benefit from:}

- Convenient online submission

- Rigorous peer review

- Open access: articles freely available online

High visibility within the field

- Retaining the copyright to your article

Submit your next manuscript at $\boldsymbol{\nabla}$ springeropen.com 